\title{
MicroRNAs in skeletal muscle and their regulation with exercise, ageing, and disease
}

\author{
Evelyn Zacharewicz, Séverine Lamon and Aaron P. Russell* \\ Centre for Physical Activity and Nutrition Research, School of Exercise and Nutrition Sciences, Deakin University, Burwood, VIC, Australia
}

\section{Edited by:}

Wataru Aoi, Kyoto Prefectural

University, Japan

Reviewed by:

Giorgos K. Sakkas, Center for

Research and Technology Hellas,

Greece

Fan Ye, University of Florida, USA

*Correspondence:

Aaron P. Russell, Centre for Physical

Activity and Nutrition Research,

School of Exercise and Nutrition

Sciences, Deakin University,

221 Burwood Highway, Burwood

3125, VIC, Australia

e-mail: aaron.russell@deakin.edu.au
Skeletal muscle makes up approximately $40 \%$ of the total body mass, providing structural support and enabling the body to maintain posture, to control motor movements and to store energy. It therefore plays a vital role in whole body metabolism. Skeletal muscle displays remarkable plasticity and is able to alter its size, structure and function in response to various stimuli; an essential quality for healthy living across the lifespan. Exercise is an important stimulator of extracellular and intracellular stress signals that promote positive adaptations in skeletal muscle. These adaptations are controlled by changes in gene transcription and protein translation, with many of these molecules identified as potential therapeutic targets to pharmacologically improve muscle quality in patient groups too ill to exercise. MicroRNAs (miRNAs) are recently identified regulators of numerous gene networks and pathways and mainly exert their effect by binding to their target messenger RNAs (mRNAs), resulting in mRNA degradation or preventing protein translation. The role of exercise as a regulatory stimulus of skeletal muscle miRNAs is now starting to be investigated. This review highlights our current understanding of the regulation of skeletal muscle miRNAs with exercise and disease as well as how they may control skeletal muscle health.

Keywords: miRNA, skeletal muscle, exercise, disease, ageing

\section{INTRODUCTION}

Maintaining skeletal muscle metabolism, size and contractile function are prerequisites for whole body health throughout life. Skeletal muscle is highly sensitive to extracellular and intracellular signals elicited by contractions from endurance and resistance exercise. These signals are the catalyst for numerous physiological adaptations including enhanced substrate metabolism, mitochondrial biogenesis, angiogenesis, muscle growth and regeneration (Hawke, 2005; Hawley et al., 2006; Léger et al., 2006; Russell, 2010). In contrast, a lack of exercise and muscle contraction, as seen in numerous neuromuscular, musculoskeletal and chronic diseases, as well as in limb immobilization following trauma, sedentary lifestyles or with ageing, negatively impacts on skeletal muscle metabolism, size and contractile function. These negative responses play a role in the on-set and progression of secondary diseases, such as diabetes and cardiovascular disease, increase the severity of chronic diseases and limit the availability of treatment options.

Extracellular and intracellular signals, activated by exercise or disease and inactivity, influence transcriptional and translational regulation of genes encoding proteins that control skeletal muscle metabolism, growth, regeneration and contraction (Dela et al., 1994; Russell et al., 2003, 2005; Short et al., 2003; Wadley et al., 2007). The control of these transcription and translation processes is regulated by transcription factor activation (Keller et al., 2001; McGee et al., 2006), histone modification (McGee et al., 2009) and DNA methylation (Nakajima et al., 2010; Barres et al., 2012). However, the discovery of microRNAs (miRNAs) (Lee et al., 1993; Reinhart et al., 2000) has revealed another level of complexity in transcriptional and translational regulation (Bartel, 2004). Our understanding of how exercise and disease regulate miRNA expression and activity as well as their messenger RNA (mRNA) targets implicated in skeletal muscle health is rudimentary. Exploring this field will advance our knowledge of the mechanisms behind skeletal muscle health and disease and potentially reveal novel therapeutic targets that may be used as a means to improve health outcomes for people suffering from muscular disorders.

\section{THE REGULATION OF mRNAs BY MicroRNAs}

MiRNAs play an imperative role in the maintenance of healthy cellular function. The primary role of miRNAs is to specifically inhibit protein expression (Olsen and Ambros, 1999; Lee et al., 2004; Wightman et al., 2004; Humphreys et al., 2005; Pillai et al., 2005; Huili et al., 2010) and this can be achieved either by degrading specific mRNA species or by repressing protein translation. Overall, mRNA degradation accounts for the majority of miRNA activity (Huili et al., 2010). The precise mechanism of miRNA targeting and activity still remains to be fully understood. However, miRNA activity appears to be largely dependent on its binding capacity to the target mRNA molecule (Brennecke et al., 2005; Hu and Bruno, 2011). Most miRNA binding sites are located in the $3^{\prime}$ untranslated region (UTR) of the target mRNA species and exist in multiple copies ( $\mathrm{Hu}$ and Bruno, 2011). There are 2 known binding types for miRNAs (Brennecke et al., 2005). The first is perfect Watson-Crick complementary binding between the $5^{\prime}$ end of the miRNA and the $3^{\prime}$ UTR of the target mRNA; although some miRNA can target the $5^{\prime}$ UTR. This region of the miRNA 
is called the "seed" region, occurring at base position $2-8$ on the $5^{\prime}$ end of the miRNA. This perfect binding within the seed region is sufficient to suppress mRNA activity on its own. The second type of binding is imperfect binding between the seed region and the $3^{\prime}$ UTR but with compensatory binding at the $3^{\prime}$ end of the mRNA molecule. Figure 1 depicts the possible types of miRNA/mRNA interactions along with the effect of miRNA binding on mRNA degradation and translational repression.

Understanding how miRNAs target and bind mRNAs has led to the development of a number of different algorithms and bioinformatics websites such as miRWalk and TargetScan (Lewis et al., 2005; Dweep et al., 2011). These softwares are commonly used to predict specific mRNA/miRNA interactions. However, miRNA binding rules are complex and are not completely understood, resulting in a lack of consensus in the literature. Foremost, establishing direct cause-and-effect links between miRNAs and mRNA targets is key to understanding the underlying molecular mechanisms behind health and disease and thus the development of effective and targeted therapies.

\section{REGULATION OF MicroRNA BIOGENESIS MACHINERY}

MiRNA biogenesis is a complex process requiring co-ordination of primary miRNA (pri-miRNA) transcription in the nucleus. The pri-miRNA is cleaved by the RNase-III type endonuclease Drosha associated with Pasha (also known as DGCR8) into a precursor molecule referred to as the pre-miRNA. The pre-miRNA is then exported into the cytoplasm by exportin 5 (XPO5) and cleaved a second time by Dicer (Lee et al., 2003; Lund et al., 2004). This gives rise to a duplex strand that is unwound by RNA helicases. The miRNA strands are separated and incorporated into the RNA-induced silencing complex (RISC), providing specificity for the RISC to identify and bind to the $3^{\prime}$ or $5^{\prime}$ UTR of the target mRNAs (Khvorova et al., 2003; Bartel, 2004; Lee et al., 2009). There has been very little investigation into the exerciseinduced regulation of the miRNA biogenesis machinery. Work from our group has shown that in the $3 \mathrm{~h}$ following a single bout of endurance exercise in untrained males there is an increase in XPO5 mRNA as well as Drosha and Dicer mRNA (Russell et al., 2013). XPO5 and Drosha mRNA are also increased in old but not young subjects within $6 \mathrm{~h}$ following a single bout of resistance exercise (Drummond et al., 2008b). Interestingly, this change

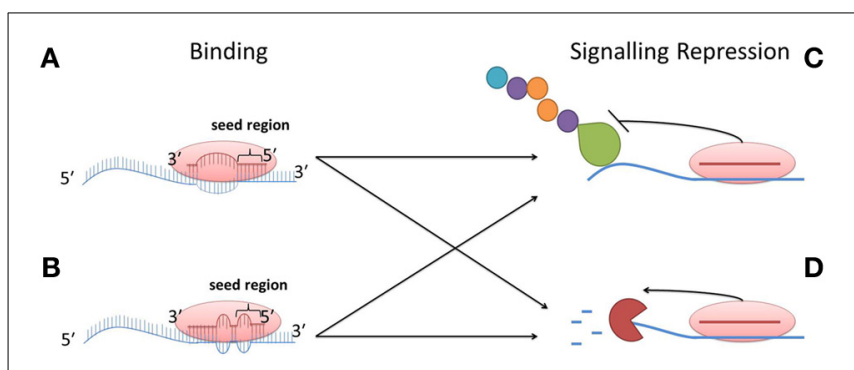

FIGURE 1 | Schematic representation of possible miRNA-mRNA interactions. (A) Perfect Watson-Crick complementary binding. (B) Imperfect binding, with compensatory binding at the $3^{\prime}$ end of the mRNA molecule. Once bound to the mRNA molecule, the miRNA can either (C) inhibit protein translation, or (D) induce mRNA degradation. occurred in parallel with a decrease in XPO5 protein levels in both groups. In addition to its role in exporting pre-miRNA from the nucleus to the cytoplasm, XPO5 also stabilizes pre-miRNAs (Lund et al., 2004), suggesting that XPO5 increases the pool of pre-miRNAs. The upregulation of XPO5 in skeletal muscle following exercise may be an adaptive response to aid processing of new pre-miRNAs that regulate exercise-induced adaptations in muscle. However, further work is required to elucidate the regulation and expression of miRNA biogenesis machinery in muscle and to understand how this affects the miRNA pool.

\section{REGULATION OF MicroRNAs IN HEALTHY MUSCLE AND EXERCISE}

Many miRNAs can be highly and specifically enriched in certain tissues (Sood et al., 2006). Skeletal muscle enriched miRNAs, referred to as myomiRs, include miR-1, miR-133a, miR-133b, miR-206, miR-208, miR-208b, miR-486 and miR-499 (McCarthy and Esser, 2007; Callis et al., 2008). The transcriptional regulation of muscle enriched miRNAs is under the control of myogenic regulatory factors (MRFs), such as MyoD, myogenin, Myf5 and MRF4 (Rao et al., 2006; Rosenberg et al., 2006), that tightly control skeletal muscle regeneration (Rudnicki and Jaenisch, 1995; Tajbakhsh et al., 1996; Sabourin and Rudnicki, 2000). These miRNAs can be arranged in polycistronic clusters and transcribed together or in parallel with protein-coding genes (Sweetman et al., 2008). MiRNAs expressed in skeletal muscle are modulated during multiple biological processes involved in skeletal muscle growth, development and maintenance, including atrophy and hypertrophy (McCarthy and Esser, 2007; McCarthy et al., 2007, 2009).

Skeletal muscle atrophy and hypertrophy models have been used to characterize the role and regulation of miRNAs potentially involved in maintaining skeletal muscle mass (see Table 1). Following 7-days of hypertrophy-inducing functional overload of the mouse plantaris muscle, expression of miR-1 and miR133 a was decreased by $50 \%$ when compared to control muscle (McCarthy and Esser, 2007). MiR-1 and miR-133a were proposed to contribute to muscle hypertrophy by the removal of their transcriptional inhibitory effect on growth factors such as IGF-1. In support of this hypothesis a regulatory feedback loop was demonstrated in vitro where IGF-1 downregulated miR-1 via the Akt/FoxO3a pathway (Elia et al., 2009). It was also shown that FoxO3a increased levels of miR-1 resulting in reduced IGF-1 protein levels.

Unloading of skeletal muscle by immobilization, hind limb suspension (HS) or exposure to microgravity during space flights decreases muscle mass (Allen et al., 2009; McCarthy et al., 2009). Muscle immobilization in rats, induced by the laceration of the tibialis anterior, is associated with a decrease in miR-1, miR133a and miR-206 levels 1 day post-intervention (Nakasa et al., 2010). MiR-107, miR-221, miR-499 and miR-208b were all downregulated following 7 days of rat HS (McCarthy et al., 2009). Eleven days of spaceflight decreased miR-206 expression (Allen et al., 2009). This decrease was paralleled by an upregulation of FoxO1, atrogin-1 and myostatin mRNAs; all regulators of muscle atrophy (Bodine et al., 2001; Kim et al., 2012). MiR-206 promotes differentiation of C2C12 myoblasts (Kim et al., 2006) and 
Table 1 | Regulation of miRNAs by exercise and disuse.



Red, downregulated; Green, upregulated; Orange, no change.

skeletal muscle regeneration following injury in mice (Liu et al., 2012). Whether miR-206 plays a direct or indirect role in repressing the atrophy genes is unknown. However, atrogin-1 degrades MyoD (Tintignac et al., 2005), which in turn positively regulates miR-206 (Chen et al., 2006); however, the existence of a miR206/MyoD/atrogin-1 regulatory loop has not been investigated.

Exercise plays an important role in maintaining muscle health throughout the lifespan, with resistance exercise a potent anabolic stimulus enhancing muscle protein synthesis and muscle growth (Fry, 2004; Léger et al., 2006; Kumar et al., 2009; Phillips, 2009; Koopman et al., 2011). Few studies have investigated the changes in skeletal muscle miRNA species following resistance exercise in humans. MiR-1 expression is reduced 3 and $6 \mathrm{~h}$ following an single bout of resistance exercise, while no changes were observed in miR-133a and miR-206 levels (Drummond et al., 2008b). Following a 12-week resistance-training program aimed at inducing muscle hypertrophy, a difference in miRNA regulation was observed in skeletal muscle of subjects defined as "high responders" vs. "low responders" to the resistance exercise training; "low responders" having little or no muscle hypertrophy following the training intervention (Davidsen et al., 2011). The training protocol resulted in an increase in skeletal muscle miR-451 expression and a decrease in miR-26a, miR-29a and miR-378 expression in the "low responder" group only. Low muscle hypertrophy response to resistance exercise training in healthy young subjects is referred to as anabolic resistance (Baar and Esser, 1999; Terzis et al., 2008); a phenomenon also linked to age-related muscle wasting or sarcopenia in the elderly. Whether miR-451, miR-26a, miR-29a and miR-378 contributes to an attenuated hypertrophy response in young healthy subjects and the mechanisms they control now requires experimental validation.

Endurance exercise is another modulator of skeletal muscle miRNA expression. Following 12 weeks of endurance training, expression of the myomiRs miR-1, miR-133a, miR-133b and miR-206 were all significantly down regulated. These miRNAs returned to pre-training baseline levels 2 weeks after the cessation of training (Nielsen et al., 2010). In contrast, 10 days of endurance training increased miR-1, concomitantly with an increase in miR-29b and a decrease in miR-31 (Russell et al., 2013). With respect to a single bout of endurance exercise, miR1 and miR-133a levels increased in the untrained state, however this acute response was not observed in the trained state (Nielsen et al., 2010). In addition, we observed that in the $3 \mathrm{~h}$ period following a single bout of endurance exercise, miR-1, -133a, -133-b 
and miR-181a were all increased. In contrast miR-9, -23a, -23b and -31 were decreased (Russell et al., 2013). We also demonstrated in vitro, via a reporter assay, that miR-31 directly interacts with HDAC4 (Russell et al., 2013), a component of the MAPK pathway (Symons et al., 2009), as well as with NRF1, which is involved in mitochondrial biogenesis and metabolism. These studies demonstrate that myomiR expression is sensitive to acute and chronic endurance exercise, as well as inactivity. However, their precise targets and the molecular processes regulated remain to be established. Other studies found no correlation between miRNA expression and components of the signaling pathways involved in skeletal muscle adaptation to endurance exercise, such as the MAPK pathway (Kramer and Goodyear, 2007) or the TGF- $\beta$ pathway (Schabort et al., 2009), suggesting that the individual myomiRs may not regulate these targets in response to endurance exercise. However, multiple miRNAs may need to work together to regulate several key proteins involved in pathway signaling. Following 6 weeks of supervised endurance training in young sedentary males $\sim 800$ gene transcripts were regulated and referred to as the training-responsive transcriptome (TRT) (Timmons et al., 2010). Three DNA sequences identified as runt-related transcription factor 1 (RUNX1), sex determining region Y box-9 (SOX9), and paired box gene-3 (PAX3) transcription factor binding sites were overexpressed in the TRT posttraining and bioinformatics analyses confirmed RUNX1, SOX9, and PAX3 as potential modulators of muscle aerobic adaptation. MiRNA screening of these subjects also identified 14 miRNAs that were decreased and 7 that were increased in skeletal muscle (Keller et al., 2011). Of the 14 miRNAs that were decreased miR-92, -98, -101 and 104 were predicted to target RUNX1, SOX9 and PAX3. This suggests that the down regulation of these $4 \mathrm{miR}-$ NAs during endurance training may permit aerobic adaptation to occur.

\section{REGULATION OF MicroRNAs IN MYOPATHIES}

MiRNAs are essential regulators of skeletal muscle health and their implication in the onset and progression of myopathies and chronic diseases associated with muscle wasting and dysfunction is of high interest. Eisenberg and colleagues observed 185 miRNAs to be commonly dysregulated across ten human primary muscular disorders (Eisenberg et al., 2007). Of these, miR-146b, miR-155, miR-214, miR-221 and miR-222 were consistently increased in almost all of the disease conditions and samples tested. Myotonic dystrophy type 1 (DM1) is the most frequently inherited neuromuscular disorder in adults. MiR-206, a regulator of muscle regeneration (Liu et al., 2012), was specifically augmented in DM1 patients when compared to healthy controls (Gambardella et al., 2010). Additionally miR-1 and miR-335 are upregulated and miR-29b, miR-29c and miR-33 downregulated in DM1 patients, when compared to control subjects suspected of a neuromuscular disorder but not presenting any pathological features (Perbellini et al., 2011). Furthermore, the cellular localization of miR-1, miR-133b and miR-206 appears disrupted in DM1 muscle. Similarly, 11 miRNAs, including the muscle enriched miRNA miR-208, are dysregulated in muscle samples from patients with myotonic dystrophy type 2 (DM2) (Greco et al., 2012).
Duchenne muscular dystrophy (DMD) is the most common and severe form of muscular dystrophy characterized by the absence of the structural membrane protein dystrophin. The muscle-enriched miR-206 is downregulated in $m d x$ mice, a wellestablished animal model for DMD (McCarthy et al., 2007; Yuasa et al., 2008) and miR-206 loss-of-function accelerates the dystrophic phenotype (Liu et al., 2012). In addition to miR-206, another 11 miRNAs were found to be dysregulated in both DMD patients and $m d x$ mice (Greco et al., 2009). In mice, these dysregulations could be rescued following therapeutic intervention, such as HDAC inhibition or restoration of nitric oxide (NO) signaling; treatments reported to ameliorate the $m d x$ phenotype (Colussi et al., 2008). In DMD samples, miR-31 and miR-486 were also identified as regulators of muscle regeneration (Greco et al., 2009). In human DMD myoblasts, miR-31 inhibition increases dystrophin content. MiR-31 modulation is therefore proposed as a possible therapeutic strategy to ameliorate the DMD phenotype (Cacchiarelli et al., 2011). Interestingly, miR-486 expression was not altered in muscle from patients with Becker muscular dystrophy who expresses a partially functional dystrophin protein (Eisenberg et al., 2007). MiR-486 is proposed to play an important regulatory role in the PTEN (phosphatase and tensin homolog deleted on chromosome 10)/Akt pathway in dystrophin deficient (Alexander et al., 2011) and normal muscle (Small et al., 2010). The sapje mutant zebrafish is a model presenting a more severe dystrophic phenotype than the $m d x$ mouse (Bassett and Currie, 2004). MiR-199a-5p is elevated in both sapje zebrafish and human DMD samples when compared to their respective control samples (Alexander et al., 2013). It was demonstrated that miR-199a-5p inhibits the expression of several components of the Wnt signaling pathway, a pathway that regulates satellite cell maintenance and differentiation (Polesskaya et al., 2003; Le Grand et al., 2009).

Chronic diseases associated with muscle wasting are associated with miRNA dysregulation. MiR-1 downregulation is observed in patients with chronic obstructive pulmonary disease (COPD) and is associated with a downregulation of the MRTF-SRF axis (Lewis et al., 2012); an important transcriptional complex regulating muscle gene expression (Cen et al., 2004; Charvet et al., 2006; Miano et al., 2007). Amyotrophic lateral sclerosis (ALS), a severe motor neuron disorder, is characterized by progressive degeneration of upper and lower motor neurons, a decline in strength, severe muscle atrophy, respiratory insufficiency (Pasinelli and Brown, 2006) and mitochondrial dysfunction (Menzies et al., 2002). We have recently identified an increase in miR-23a in skeletal muscle of ALS patients when compared to healthy controls (Russell et al., 2012). It was established in vitro that miR-23a negatively regulates peroxisome proliferator-activated receptor gamma coactivator 1-alpha (PGC-1 $\alpha$ ) (Russell et al., 2012), a key activator of mitochondrial biogenesis and function. Therapeutic inhibition of miR-23a may rescue PGC- $1 \alpha$ activity and ameliorate the ALS phenotype, however this remains to be established. Sixteen miRNAs were dysregulated in patients with laminopathies, a class of myopathies presenting mutations in the lamin A/C gene (Sylvius et al., 2011). Of these, miR-100, miR-192 and miR-135, were directly involved in C2C12 myoblast proliferation and differentiation. In muscle from children suffering from dermatomyositis, an upregulation of 33 miRNAs was observed 
(Eisenberg et al., 2007). However, miR-126 was specifically downregulated in patients in the early stage of the disease when compared to healthy controls (Kim et al., 2012). MiR-126 is proposed to play a specific role in the early but not in the late stage of juvenile dermatomyositis by promoting the expression of the vascular cell adhesion molecule 1 (VCAM-1), a protein normally expressed in developing but not in mature healthy muscle fibers.

MiRNAs are responsible for the regulation of numerous gene networks and pathways in muscle. Consequently, they are important modulators of skeletal muscle health and many miRNAs are dysregulated in specific muscle disease conditions. Some of these miRNAs play a direct role in muscle cell proliferation or differentiation; however, whether the changes observed in miRNA levels actively contribute or are a consequence of the disease development remains mostly unknown. Identifying the miRNAs dysregulated and understanding their role in muscle diseases is therefore a crucial step in the development of targeted therapeutic strategies.

\section{AGE-ASSOCIATED REGULATION OF MicroRNAs IN SKELETAL MUSCLE}

Ageing is a condition associated with changes in skeletal muscle size and function as well as the regulation of miRNAs. Ageing studies using $C$. elegans identified changes in miRNAs associated with lifespan and cellular senescence (Boehm and Slack, 2005; Ibáñez-Ventoso et al., 2006; Yamakuchi and Lowenstein, 2009; De Lencastre et al., 2010). Of particular interest, let-7 miRNA is decreased with age in C. elegans (Ibáñez-Ventoso et al., 2006; De Lencastre et al., 2010). In contrast, observations in older humans have identified that two miRNAs from the let-7 family of miRNAs, let-7b and let-7e, are elevated in skeletal muscle when compared to young subjects (Drummond et al., 2008a, 2011). The sequence of C. elegans (cel)-let-7 varies slightly from human (has)-let-7b and hsa-let-7e and this difference may be sufficient to confer different mRNA targets for these three miRNAs. Caution must be taken when comparing the expression of miRNAs between different species. MiRNAs have historically been named in the same order as they have been discovered. However, occasional discrepancies exist between species; therefore, a direct comparison between correspondingly named miRNAs cannot always be made. In addition, the mRNAs targeted by a same miRNA can differ between species, although their biological function can be conserved. The function of the let-7 family of miRNAs is similar in both $C$. elegans and humans. The primary role of the let-7 miRNAs appears to be anti-proliferative, as observed in human cancer cells (Johnson et al., 2007; Nishino et al., 2008; Dong et al., 2010; Zhao et al., 2010; Lee et al., 2011) and in mouse neuronal stem cells (Nishino et al., 2008). The elevation of let-7 miRNAs may be responsible for the impaired ability to activate and proliferate satellite cells in the elderly skeletal muscle, therefore contributing to the attenuated skeletal muscle regenerative capacity in the elderly (Carlson et al., 2009). Accordingly, bioinformatics analysis identified cell cycle regulation and cellular growth and proliferation as the most highly ranked cellular processes likely to be regulated by the 2 let- 7 miRNAs in humans. In old mice with muscle atrophy, 57 miRNAs were differentially regulated in the quadriceps when compared to young mice (Hamrick et al., 2010).
Of the dysregulated miRNAs, several were predicted to target genes involved in myogenesis, including Mef2, SRF, cardiotrophin 1 , myogenin and the cell cycle regulator type IIA activin receptor. Figure 2 summarizes the known and potential roles of miRNAs in myogenesis in the elderly. In order to elucidate which of these miRNAs are important in the age-related muscle wasting, their mRNA targets and specific roles in muscle regeneration and protein synthesis need to be established.

The most natural way to promote muscle growth is by ingesting good quality protein and engaging in resistance exercise training which is able to stimulate muscle protein synthesis (Yarasheski et al., 1993; Hasten et al., 2000; Drummond et al., 2008a; Katsanos et al., 2008; Kumar et al., 2009; Symons et al., 2009). However, elderly subjects demonstrate an impaired protein synthetic response to resistance exercise (Cuthbertson et al., 2005; Kumar et al., 2009). To date, only one study has investigated the expression of miRNAs in young and old subjects following a protein-stimulating intervention protocol (Drummond et al., 2008b). MiR-1, miR-133a and miR-206 were measured in the muscle of young and old subjects following an acute bout of resistance exercise and ingestion of essential amino acids (EAA). Only miR-1 expression was reduced in the young, but not the old subjects, 3 and $6 \mathrm{~h}$ post-exercise and EAA ingestion. A regulatory role for miR-1 as an IGF-1 inhibitor has previously been established (McCarthy and Esser, 2007; Elia et al., 2009). Failure to downregulate miR-1 in elderly subjects following an




acute bout of resistance exercise and EAA ingestion may be partially responsible for the attenuated muscle protein synthesis in response to anabolic stimuli. However, more miRNA targets need to be investigated to fully appreciate the role of miRNAs in age-related muscle wasting and to understand the potential mechanisms attenuating protein synthesis following resistance exercise.

\section{MicroRNAs AS BIOMARKERS OF DISEASE AND EXERCISE-INDUCED ADAPTATION}

A key feature of miRNAs is their resistance to ribonucleases (RNases) and therefore their presence and potential stability in blood (Chen et al., 2008; Gilad et al., 2008; Turchinovich et al., 2011). Indeed, miRNAs exist within exosomes, lipoprotein and ribonucleoprotein complexes, which protect them from RNases digestion (Valadi et al., 2007; Zhang et al., 2010; Vickers et al., 2011). MiRNAs can be highly expressed in specific tissues, (Sood et al., 2006) although their role in circulation is not yet clear. Circulating miRNAs can originate from tissues with hematopoietic cells an abundant source of circulating miRNAs (Kosaka et al., 2010; Pritchard et al., 2012).

The existence and stability of miRNAs in circulation has led to the search for miRNA biomarkers for various diseases such as cancer, type 2 diabetes, hepatic diseases and coronary diseases

Table 2 | Regulation of circulating miRNAs by exercise, training, and fitness level.

\begin{tabular}{|c|c|c|c|c|c|c|c|c|c|c|c|c|}
\hline Author & Subjects & Model & Extraction kit & Sample & \multicolumn{8}{|c|}{ MiRs } \\
\hline $\begin{array}{l}\text { Baggish } \\
\text { et al., } 2011\end{array}$ & $\begin{array}{l}\text { Endurance } \\
\text { athletes }\end{array}$ & $\begin{array}{l}\text { Endurance } \\
\text { acute exercise } \\
\text { bout and } \\
\text { training }\end{array}$ & $\begin{array}{l}\text { MicroRNA } \\
\text { Extraction Kit, } \\
\text { Benevbio, } \\
\text { Mission Viejo, } \\
\text { CA, USA }\end{array}$ & Plasma & $\operatorname{miR}-146 a$ & $\operatorname{miR}-21$ & miR-20a & miR-222 & $\operatorname{miR}-221$ & $\operatorname{miR}-210$ & miR-133a & miR-328 \\
\hline $\begin{array}{l}\text { Uhlemann } \\
\text { et al., } 2012\end{array}$ & Not specified & $\begin{array}{l}\text { Endurance } \\
\text { acute maximal } \\
\text { exercise bout }\end{array}$ & $\begin{array}{l}\text { Qiagen } \\
\text { miRNAeasy, } \\
\text { Hilden, } \\
\text { Germany }\end{array}$ & Plasma & miR-126 & miR-133 & & & & & & \\
\hline $\begin{array}{l}\text { Uhlemann } \\
\text { et al., } 2012\end{array}$ & Trained & $\begin{array}{l}\text { Endurance } \\
\text { acute } \\
\text { submaximal } \\
\text { exercise bout }\end{array}$ & $\begin{array}{l}\text { Qiagen } \\
\text { miRNAeasy, } \\
\text { Hilden, } \\
\text { Germany }\end{array}$ & Plasma & miR-126 & miR-133 & & & & & & \\
\hline $\begin{array}{l}\text { Uhlemann } \\
\text { et al., } 2012\end{array}$ & Trained & $\begin{array}{l}\text { Endurance } \\
\text { marathon race }\end{array}$ & $\begin{array}{l}\text { Qiagen } \\
\text { miRNAeasy, } \\
\text { Hilden, } \\
\text { Germany }\end{array}$ & Plasma & miR-126 & miR-133 & & & & & & \\
\hline $\begin{array}{l}\text { Uhlemann } \\
\text { et al., } 2012\end{array}$ & Trained & $\begin{array}{l}\text { Resistance } \\
\text { acute exercise } \\
\text { bout }\end{array}$ & $\begin{array}{l}\text { Qiagen } \\
\text { miRNAeasy, } \\
\text { Hilden, } \\
\text { Germany }\end{array}$ & Plasma & miR-126 & miR-133 & & & & & & \\
\hline $\begin{array}{l}\text { Aoi } \\
\text { et al., } 2013\end{array}$ & Untrained & $\begin{array}{l}\text { Endurance } \\
\text { acute exercise } \\
\text { bout } \\
\text { and training }\end{array}$ & $\begin{array}{l}\text { TRIzol LS, } \\
\text { Invitrogen, } \\
\text { Carlsbad, CA }\end{array}$ & Serum & $\frac{m i R-486}{m i R-486}$ & & & & & & & \\
\hline $\begin{array}{l}\text { Bye } \\
\text { et al., } 2013\end{array}$ & & $\begin{array}{l}\text { Low v High } \\
\text { fitness }\end{array}$ & miRNeasy & Serum & miR-210 & $\operatorname{miR}-222$ & miR-21 & & & & & \\
\hline $\begin{array}{l}\text { Sawada } \\
\text { et al., } 2013\end{array}$ & $\begin{array}{l}\text { Recreationally } \\
\text { active }\end{array}$ & $\begin{array}{l}\text { Resistance } \\
\text { acute exercise } \\
\text { bout }\end{array}$ & $\begin{array}{l}\text { QIAzol- } \\
\text { chloroform- } \\
\text { column } \\
\text { extraction }\end{array}$ & Serum & $\begin{array}{l}\text { miR-149* } \\
\text { (I h post) }\end{array}$ & $\begin{array}{c}\text { miR-146a } \\
\text { (3 days } \\
\text { post) }\end{array}$ & $\begin{array}{r}\text { miR-221 (3 } \\
\text { days post) }\end{array}$ & $\operatorname{miR}-133 a$ & & & & \\
\hline $\begin{array}{l}\text { Roberts } \\
\text { et al., } 2013\end{array}$ & & $M d x$ mouse & $\begin{array}{l}\text { TRIzol LS, } \\
\text { Paisley, UK and } \\
\text { Qiagen } \\
\text { miRNeasy® } \\
\text { Mini Kit, } \\
\text { Crawley, UK }\end{array}$ & Serum & miR-1 & $\operatorname{miR}-133 a$ & miR-206 & miR-22 & miR-30a & $\begin{array}{l}\text { miR- } \\
193 b\end{array}$ & miR-378 & \\
\hline $\begin{array}{l}\text { Roberts } \\
\text { et al., } 2013\end{array}$ & & $\begin{array}{l}\text { C57B1/10 } \\
\text { mice with } \\
\text { intramuscular } \\
\text { cardiotoxin } \\
\text { injection }\end{array}$ & $\begin{array}{l}\text { TRIzol LS, } \\
\text { Paisley, UK }\end{array}$ & Serum & $\operatorname{miR}-1$ & $\operatorname{miR}-133 a$ & miR-206 & & & & & \\
\hline
\end{tabular}

Circulating miRNAs regulated by acute exercise were measured immediately post-exercise. Red, downregulated; Green, upregulated; Orange, no change. 
(Chen et al., 2008; Mitchell et al., 2008; D’Alessandra et al., 2010; Huang et al., 2010; Pigati et al., 2010; Brase et al., 2011; Freedman et al., 2012). Aberrant expression of specific miRNAs in the circulation may be reflective of disease burden in a specific tissue. It follows that circulating miRNAs may be beneficial as biomarkers for skeletal muscle disease or skeletal muscle adaptation to exercise. To date, only one study has looked at the circulating miRNAs dysregulated in a muscle disorder. Roberts et al. identified an increase in 57 circulating miRNAs in the $m d x$ mouse when compared to wild-type controls (Roberts et al., 2013), including miR-1, miR-133a, and miR-206. The same study demonstrated that miR-1 levels were elevated in the serum of wild-type mice 15 min after a cardiotoxin injection in the tibialis anterior muscle, suggesting that high levels of circulating miR-1 are associated with muscle degeneration and injury.

Changes in plasma and whole blood miRNA profiles have been observed following acute and chronic exercise and in association with training-induced changes in muscle performance (Baggish et al., 2011; Uhlemann et al., 2012; Aoi et al., 2013; Bye et al., 2013; Sawada et al., 2013; Tonevitsky et al., 2013). Table 2 summarizes the circulating miRNAs regulated by exercise, training and fitness level. Circulating miR-133a increases immediately following a marathon race and a single bout of resistance exercise (lateral pulldown, leg press, butterfly) (Uhlemann et al., 2012) but not after a single bout of cycling or treadmill exercise (Baggish et al., 2011; Uhlemann et al., 2012) in trained subjects. In contrast, circulating miR-133a was too lowly expressed at rest and following cycling exercise to be reliably measured (Aoi et al., 2013). Immediately following an acute bout of resistance exercise (bench press and bilateral leg press) in untrained subjects, no changes in circulating miRNA expression was observed (Sawada et al., 2013). Circulating miR-21 and miR222 are increased following a single bout of cycling exercise and after 90 days of rowing training (Baggish et al., 2011). However, circulating miR-21 and miR-222 appear highly expressed in individuals with low $\mathrm{VO}_{2 \max }$ when compared to individuals with high $\mathrm{VO}_{2 \max }$ (Bye et al., 2013). These discrepancies may be explained by differences in the exercise protocols used. However, it is becoming apparent that various RNA extraction protocols introduce differences in the expression levels of the measured miRNAs (McAlexander et al., 2013). In addition, hemolysis is a major source of plasma miRNAs (Pritchard et al., 2012) and caution needs to be taken during blood draw and plasma separation to avoid miRNA contamination from red blood cells. The expression of plasma miRNAs derived from hematopoietic cells

\section{REFERENCES}

Alexander, M. S., Casar, J. C., Motohashi, N., Myers, J. A., Eisenberg, I., Gonzalez, R. T., et al. (2011). Regulation of DMD pathology by an ankyrin-encoded miRNA. Skelet. Muscle 1, 27. doi: 10.1186/20445040-1-27

Alexander, M. S., Kawahara, G., Motohashi, N., Casar, J. C., Eisenberg, I., Myers, J. A., et al. (2013). MicroRNA-199a is induced

correlates strongly with hematopoietic cell number (Pritchard et al., 2012). Therefore, changes in circulating miRNA levels within subjects may reflect exercise-induced changes in blood cell numbers (Tanimura et al., 2009; Connes et al., 2013; Tonevitsky et al., 2013) rather than muscle-specific adaptations. Tonevitsky et al. completed a miRNA array in whole blood of trained individuals following a single bout of treadmill exercise. MiR-215p, miR-24-2-5p, miR-27a-5p, miR-181a-5p and miR-181b-5p were all regulated immediately post-exercise and during recovery (Tonevitsky et al., 2013). Bioinformatics analysis predicted these miRNAs to target exercise-responsive processes including immune function, apoptosis, membrane trafficking and transcriptional regulation. However, these relationships have not been experimentally validated.

An ideal miRNA biomarker candidate for muscle disease or adaptation to exercise should not be expressed by hematopoietic cells but rather be predominantly expressed in the tissue of interest, such as miR-133a (Callis et al., 2008) and miR-210; the latter described as a hypoximiR (Devlin et al., 2011). More work is required to determine whether circulating miRNAs can serve as stable blood-based biomarkers for underlying skeletal muscle diseases and exercise-induced muscle adaptations.

\section{CONCLUDING REMARKS}

MiRNAs are positive regulators of myogenesis. Their expression levels change following a single bout of exercise and exercise training and following nutritional interventions. A dysregulation of various miRNAs occurs in myopathies, in chronic diseases associated with muscle atrophy as well as with ageing. These observations suggest that skeletal muscle miRNAs play an important role in muscle adaptation and maladaptation. The identification of circulating miRNAs and their regulation following exercise and in disease suggests that they may be useful biomarkers of health and adaptation to treatment interventions. These observations also imply that miRNAs might be amenable to therapeutic intervention. However, at present we have little knowledge relating to how changes in skeletal muscle or circulating miRNAs influence, either directly or indirectly, changes in skeletal muscle regeneration, size, function, metabolism and consequently whole body health. Establishing the causal roles of skeletal muscle miRNAs in vivo is now required to significantly advance this exciting field.

\section{ACKNOWLEDGMENTS}

Séverine Lamon is supported by an Alfred Deakin postdoctoral fellowship from Deakin University.

Aoi, W., Ichikawa, H., Mune, K., Tanimura, Y., Mizushima, K., Naito, Y., et al. (2013). Muscleenriched microRNA miR-486 decreases in circulation in response to exercise in young men. Front. Physiol. 4:80. doi: 10.3389/fphys. 2013.00080

Baar, K., and Esser, K. (1999). Phosphorylation of $\mathrm{p} 70^{56 k}$ correlates with increased skeletal muscle mass following resistance exercise. Am.
J. Physiol. Cell Physiol. 276, C120-C127.

Baggish, A. L., Hale, A., Weiner, R. B., Lewis, G. D., Systrom, D., Wang, F., et al. (2011). Dynamic regulation of circulating microRNA during acute exhaustive exercise and sustained aerobic exercise training. J. Physiol. 589, 3983-3994. doi: 10.1113/jphysiol.2011.213363

Barres, R., Yan, J., Egan, B., Treebak, J. T., Rasmussen, M., Fritz, T., et al. (2012). Acute exercise 
remodels promoter methylation in human skeletal muscle. Cell Metab. 15, 405-411. doi: 10.1016/j.cmet.2012.01.001

Bartel, D. P. (2004). MicroRNAs: genomics, biogenesis, mechanism, and function. Cell 116, 281-297. doi: $\quad 10.1016 /$ S0092-8674(04) 00045-5

Bassett, D., and Currie, P. D. (2004). Identification of a zebrafish model of muscular dystrophy. Clin. Exp. Pharmacol. Physiol. 31, 537-540. doi: $\quad 10.1111 /$ j.1440-1681.2004. 04030.x

Bodine, S. C., Latres, E., Baumhueter, S., Lai, V. K. M., Nonez, L., Clarke, B. A., et al. (2001). Identification of ubiquitin ligases required for skeletal muscle atrophy. Science 294, 1704. doi: 10.1126/science. 1065874

Boehm, M., and Slack, F. (2005). A developmental timing microRNA and its target regulate life span in C. elegans. Science 310, 1954-1957. doi: 10.1126/science. 1115596

Brase, J. C., Johannes, M., Schlomm, T., Fälth, M., Haese, A., Steuber, T., et al. (2011). Circulating miRNAs are correlated with tumor progression in prostate cancer. Int. J. Cancer 128, 608-616. doi: 10.1002/ijc. 25376

Brennecke, J., Stark, A., Russell, R. B., and Cohen, S. M. (2005). Principles of MicroRNA-target recognition. PLoS Biol. 3:e85. doi: 10.1371/journal.pbio.0030085

Bye, A., Røsjø, H., Aspenes, S. T., Condorelli, G., Omland, T., and Wisløff, U. (2013). Circulating MicroRNAs and aerobic fitness - The HUNTStudy. PLOS ONE 8:e57496. doi: 10.1371/journal.pone.0057496

Cacchiarelli, D., Incitti, T., Martone, J., Cesana, M., Cazzella, V., Santini, T., et al. (2011). miR-31 modulates dystrophin expression: new implications for Duchenne muscular dystrophy therapy. EMBO Rep. 12, 136-141. doi: 10.1038/embor.2010.208

Callis, T. E., Deng, Z., Chen, J.-F., and Wang, D.-Z. (2008). Muscling Through the microRNA World. Exp. Biol. Med. 233, 131-138. doi: 10.3181/0709-MR-237

Carlson, M. E., Suetta, C., Conboy, M. J., Aagaard, P., Mackey, A., Kjaer, M., et al. (2009). Molecular aging and rejuvenation of human muscle stem cells. EMBO Mol. Med. 1, 381-391. doi: 10.1002/emmm.200900045

Cen, B., Selvaraj, A., and Prywes, R. (2004). Myocardin/MKL family of SRF coactivators: key regulators of immediate early and muscle specific gene expression. J. Cell. Biochem. 93, 74-82. doi: 10.1002/jcb.20199

Charvet, C., Houbron, C., Parlakian, A., Giordani, J., Lahoute, C., Bertrand, A., et al. (2006). New role for serum response factor in postnatal skeletal muscle growth and regeneration via the interleukin 4 and insulin-like growth factor 1 pathways. Mol. Cell. Biol. 26, 6664-6674. doi: 10.1128/MCB.00138-06

Chen, J.-F., Mandel, E. M., Thomson, J. M., Wu, Q., Callis, T. E., Hammond, S. M., et al. (2006). The role of microRNA-1 and microRNA133 in skeletal muscle proliferation and differentiation. Nat. Genet. 38, 228-233. doi: 10.1038/ng1725

Chen, X., Ba, Y., Ma, L., Cai, X., Yin, Y., Wang, K., et al. (2008). Characterization of microRNAs in serum: a novel class of biomarkers for diagnosis of cancer and other diseases. Cell Res. 18, 997-1006. doi: 10.1038/cr.2008.282

Colussi, C., Mozzetta, C., Gurtner, A., Illi, B., Rosati, J., Straino, S., et al. (2008). HDAC2 blockade by nitric oxide and histone deacetylase inhibitors reveals a common target in Duchenne muscular dystrophy treatment. Proc. Natl. Acad. Sci. U.S.A. 105, 19183-19187. doi: 10.1073/pnas.0805514105

Connes, P., Simmonds, M. J., Brun, J.-F., and Baskurt, O. K. (2013). Exercise hemorheology: classical data, recent findings and unresolved issues. Clin. Hemorheol. Microcirc. 53, 187-199.

Cuthbertson, D., Smith, K., Babraj, J., Leese, G., Waddell, T., Atherton, P., et al. (2005). Anabolic signaling deficits underlie amino acid resistance of wasting, aging muscle. FASEB J. 19, 422-424.

D’Alessandra, Y., Devanna, P., Limana, F., Straino, S., Di Carlo, A., Brambilla, P. G., et al. (2010). Circulating microRNAs are new and sensitive biomarkers of myocardial infarction. Eur. Heart J. 31, 2765-2773. doi: 10.1093/eurheartj/ehq167

Davidsen, P. K., Gallagher, I. J., Hartman, J. W., Tarnopolsky, M. A., Dela, F., Helge, J. W., et al. (2011). High responders to resistance exercise training demonstrate differential regulation of skeletal muscle microRNA expression. J. Appl. Physiol. 110, 309-317. doi: 10.1152/japplphysiol.00901.2010

De Lencastre, A., Pincus, Z., Zhou, K., Kato, M., Lee, S. S., and Slack, F. J. (2010). MicroRNAs both promote and antagonize longevity in C. elegans. Curr. Biol. 20, 2159-2168. doi: 10.1016/j.cub.2010.11.015
Dela, F., Ploug, T., Handberg, A., Petersen, L. N., Larsen, J. J., Mikines, K. J., et al. (1994). Physical training increases muscle GLUT4 protein and mRNA in patients with NIDDM. Diabetes 43, 862-865. doi: 10.2337/diabetes.43.7.862

Devlin, C., Greco, S., Martelli, F., and Ivan, M. (2011). miR-210: more than a silent player in hypoxia. IUBMB Life 63, 94-100.

Dong, Q., Meng, P., Wang, T., Qin, W., Qin, W., Wang, F., et al. (2010). MicroRNA Let-7a inhibits proliferation of human prostate cancer cells in vitro and in vivo by targeting $\mathrm{E} 2 \mathrm{~F} 2$ and CCND2. PLOS ONE 5:e10147. doi: 10.1371/journal.pone.0010147

Drummond, M. J., Dreyer, H. C., Pennings, B., Fry, C. S., Dhanani, S., Dillon, E. L., et al. (2008a). Skeletal muscle protein anabolic response to resistance exercise and essential amino acids is delayed with aging. J. Appl. Physiol. 104, 1452-1461. doi: 10.1152/japplphysiol.00021.2008

Drummond, M. J., McCarthy, J. J., Fry, C. S., Esser, K. A., and Rasmussen, B. B. (2008b). Aging differentially affects human skeletal muscle microRNA expression at rest and after an anabolic stimulus of resistance exercise and essential amino acids. Am. J. Physiol. Endocrinol. Metab. 58, E1333-E1340. doi: 10.1152/ajpendo.90562.2008

Drummond, M. J., McCarthy, J. J., Sinha, M., Spratt, H. M., Volpi, E., Esser, K. A., et al. (2011). Aging and microRNA expression in human skeletal muscle: a microarray and bioinformatics analysis. Physiol. Genomics 43 , 595-603. doi: 10.1152/physiolgenomics.00148.2010

Dweep, H., Sticht, C., Pandey, P., and Gretz, N. (2011). miRWalk - database: prediction of possible miRNA binding sites by "walking" the genes of three genomes. J. Biomed. Inform. 44, 839-847. doi: 10.1016/j.jbi.2011. 05.002

Eisenberg, I., Eran, A., Nishino, I., Moggio, M., Lamperti, C., Amato, A. A., et al. (2007). Distinctive patterns of microRNA expression in primary muscular disorders. Proc. Natl. Acad. Sci. U.S.A. 104, 17016-17021. doi: 10.1073/pnas.0708115104

Elia, L., Contu, R., Quintavalle, M., Varrone, F., Chimenti, C., Russo, M. A., et al. (2009). Reciprocal regulation of MicroRNA-1 and insulin-like growth factor-1 signal transduction cascade in cardiac and skeletal muscle in physiological and pathological conditions. Circulation
120, 2377-2385. doi: 10.1161/ CIRCULATIONAHA.109.879429

Freedman, J., Ercan, B., Morin, K., Liu, C.-T., Tamer, L., Ayaz, L., et al. (2012). The distribution of circulating microRNA and their relation to coronary disease. F1000 Res. [Epub ahead of print].

Fry, A. C. (2004). The role of resistance exercise intensity on muscle fibre adaptations. Sports Med. 34, 663-679. doi: 10.2165/00007256200434100-00004

Gambardella, S., Rinaldi, F., Lepore, S. M., Viola, A., Loro, E., Angelini, C., et al. (2010). Overexpression of microRNA-206 in the skeletal muscle from myotonic dystrophy type 1 patients. J. Transl. Med. 8, 48. doi: 10.1186/1479-5876-8-48

Gilad, S., Meiri, E., Yogev, Y., Benjamin, S., Lebanony, D., Yerushalmi, N., et al. (2008). Serum MicroRNAs are promising novel biomarkers. PLoS ONE 3:e3148. doi: 10.1371/journal.pone.0003148

Greco, S., Perfetti, A., Fasanaro, P., Cardani, R., Capogrossi, M. C., Meola, G., et al. (2012). Deregulated microRNAs in myotonic dystrophy type 2. PLoS ONE 7:e39732. doi: 10.1371/journal. pone.0039732

Greco, S., Simone, M. D., Colussi, C., Zaccagnini, G., Fasanaro, P., Pescatori, M., et al. (2009). Common micro-RNA signature in skeletal muscle damage and regeneration induced by Duchenne muscular dystrophy and acute ischemia. FASEB J. 23, 3335-3346. doi: 10.1096/fj.08-128579

Hamrick, M. W., Herberg, S., Arounleut, P., He, H.-Z., Shiver, A., Qi, R.-Q., et al. (2010). The adipokine leptin increases skeletal muscle mass and significantly alters skeletal muscle miRNA expression profile in aged mice. Biochem. Biophys. Res. Commun. 400, 379-383. doi: 10.1016/j.bbrc. 2010.08.079

Hasten, D. L., Pak-Loduca, J., Obert, K. A., and Yarasheski, K. E. (2000). Resistance exercise acutely increases MHC and mixed muscle protein synthesis rates in 78-84 and 23-32 yr olds. Am. J. Physiol. Endocrinol. Metab. 278, E620-E626.

Hawke, T. J. (2005). Muscle stem cells and exercise training. Exerc. Sport Sci. Rev. 33, 63-68. doi: 10.1097/000 03677-200504000-00002

Hawley, J. A., Hargreaves, M., and Zierath, J. R. (2006). Signalling mechanisms in skeletal muscle: role in substrate selection and muscle adaptation. Essays Biochem. 42, 1-12. doi: 10.1042/bse0420001 
Hu, Z., and Bruno, A. E. (2011). The Influence of $3^{\prime} \mathrm{UTR}$ s on MicroRNA function inferred from human SNP data. Comp. Funct. Genomics 2011:910769. doi: 10.1155/2011/ 910769

Huang, Z., Huang, D., Ni, S., Peng, Z., Sheng, W., and Du, X. (2010). Plasma microRNAs are promising novel biomarkers for early detection of colorectal cancer. Int. J. Cancer 127, 118-126. doi: $10.1002 / \mathrm{ijc} .25007$

Huili, G., Ingolia, N. T., Weissman, J. S., and Bartel, D. P. (2010). Mammalian microRNAs predominantly act to decrease target mRNA levels. Nature 466, 835-840. doi: 10.1038 /nature09267

Humphreys, D. T., Westman, B. J., Martin, D. I. K., and Preiss, T. (2005). MicroRNAs control translation initiation by inhibiting eukaryotic initiation factor 4E/cap and poly(A) tail function. (English). Proc. Natl. Acad. Sci. U.S.A. 102, 16961-16966. doi: 10.1073/pnas.0506482102

Ibáñez-Ventoso, C., Yang, M., Guo, S., Robins, H., Padgett, R. W., and Driscoll, M. (2006). Modulated microRNA expression during adult lifespan in Caenorhabditis elegans. Aging Cell 5, 235-246. doi: 10.1111/ j.1474-9726.2006.00210.x

Johnson, C. D., Esquela-Kerscher, A., Stefani, G., Byrom, M., Kelnar, K., Ovcharenko, D., et al. (2007). The let-7 microRNA represses cell proliferation pathways in human cells. Cancer Res. 67, 7713-7722. doi: 10.1158/0008-5472.CAN-07-1083

Katsanos, C. S., Chinkes, D. L., PaddonJones, D., Zhang, X.-J., Aarsland, A., and Wolfe, R. R. (2008). Whey protein ingestion in elderly persons results in greater muscle protein accrual than ingestion of its constituent essential amino acid content. Nutr. Res. 28, 651-658. doi: 10.1016/j.nutres.2008.06.007

Keller, C., Steensberg, A., Pilegaard, H., Osada, T., Saltin, B., Pedersen, B. K., et al. (2001). Transcriptional activation of the IL-6 gene in human contracting skeletal muscle: influence of muscle glycogen content. FASEB J. 15, 2748-2750.

Keller, P., Vollaard, N. B., Gustafsson, T., Gallagher, I. J., Sundberg, C. J., Rankinen, T., et al. (2011). A transcriptional map of the impact of endurance exercise training on skeletal muscle phenotype. J. Appl. Physiol. 110, 46-59. doi: 10.1152/japplphysiol.00634.2010

Khvorova, A., Reynolds, A., and Jayasena, S. D. (2003). Functional
siRNAs and miRNAs exhibit strand bias. Cell 115, 209. doi: 10.1016/S0092-8674(03)00801-8

Kim, E., Cook-Mills, J., Morgan, G., Sredni, S. T., and Pachman, L. M. (2012). Increased expression of vascular cell adhesion molecule 1 in muscle biopsy samples from juvenile dermatomyositis patients with short duration of untreated disease is regulated by miR- 126 . Arthritis Rheum. 64, 3809-3817. doi: 10.1002/art.34606

Kim, H. K., Lee, Y. S., Sivaprasad, U., Malhotra, A., and Dutta, A. (2006). Muscle-specific microRNA miR-206 promotes muscle differentiation. J. Cell Biol. 174, 677-687. doi: 10.1083/jcb.200603008

Koopman, R., Gleeson, B., Gijsen, A. P., Groen, B., Senden, J. M. G., Rennie M. J., et al. (2011). Post-exercise protein synthesis rates are only marginally higher in type I compared with type II muscle fibres following resistance-type exercise. Eur. J. Appl. Physiol. 111, 1871-1878. doi: 10.1007/s00421-010-1808-9

Kosaka, N., Iguchi, H., and Ochiya, T. (2010). Circulating microRNA in body fluid: a new potential biomarker for cancer diagnosis and prognosis. Cancer Sci. 101, 2087-2092. doi: 10.1111/j.13497006.2010.01650.x

Kramer, H. F., and Goodyear, L. J. (2007). Exercise, MAPK, and NFkappaB signaling in skeletal muscle. J. Appl. Physiol. 103, 388-395. doi: 10.1152/japplphysiol.00085.2007

Kumar, V., Selby, A., Rankin, D. Patel, R., Atherton, P., Hildebrandt, W., et al. (2009). Age-related differences in the dose-response relationship of muscle protein synthesis to resistance exercise in young and old men. J. Physiol. 587, 211-217. doi: 10.1113/jphysiol. 2008.164483

Lee, I., Ajay, S. S., Yook, J. I., Kim, H. S., Hong, S. H., Kim, N. H., et al. (2009). New class of microRNA targets containing simultaneous 5'UTR and 3'-UTR interaction sites. Genome Res. 19, 1175-1183. doi: 10.1101/gr.089367.108

Lee, R. C., Feinbaum, R. L., and Ambros, V. (1993). The C. elegans heterochronic gene lin4 encodes small RNAs with antisense complementarity to lin-14. Cell 75, 843-854. doi: 10.1016/0092-8674(93)90529-Y

Lee, S.-T., Chu, K., Oh, H.-J., Im, W.-S., Lim, J.-Y., Kim, S.-K., et al. (2011). Let-7 microRNA inhibits the proliferation of human glioblastoma cells. J. Neurooncol. 102, 19-24. doi: 10.1007/s11060-010-0286-6
Lee, S. W., Dai, G., Hu, Z., Wang, X., Du, J., and Mitch, W. E. (2004). Regulation of muscle protein degradation: coordinated control of apoptotic and Ubiquitin-Proteasome systems by Phosphatidylinositol 3 kinase. J. Am. Soc. Nephrol. 15, 1537-1545. doi: 10.1097/01.ASN.0000127211. 86206.E1

Lee, Y., Ahn, C., Han, J., Choi, H., Kim, J., Yim, J., et al. (2003). The nuclear RNase III drosha initiates microRNA processing. Nature 425 , 415-419. doi: 10.1038/nature01957

Léger, B., Cartoni, R., Praz, M., Lamon, S., Dériaz, O., Crettenand, A., et al. (2006). Akt signalling through GSK-3beta, mTOR and Foxol is involved in human skeletal muscle hypertrophy and atrophy. J. Physiol. 576, 923-933. doi: 10.1113/jphysiol.2006.116715

Le Grand, F., Jones, A. E., Seale, V. Scimè, A., and Rudnicki, M. A (2009). Wnt7a activates the planar cell polarity pathway to drive the symmetric expansion of satellite stem cells. Cell Stem Cell 4, 535-547. doi: 10.1016/j.stem.2009.03.013

Lewis, A., Riddoch-Contreras, J. Natanek, S. A., Donaldson, A. Man, W. D., Moxham, J., et al. (2012). Downregulation of the serum response factor/miR-1 axis in the quadriceps of patients with COPD. Thorax 67, 26-34. doi: 10.1136/thoraxinl-2011-200309

Lewis, B. P., Burge, C. B., and Bartel D. P. (2005). Conserved seed pairing, often flanked by adenosines, indicates that thousands of human genes are MicroRNA targets. Cell 120, 15-20. doi: 10.1016/j.cell.2004. 12.035

Liu, N., Williams, A. H., Maxeiner, J. M., Bezprozvannaya, S., Shelton, J. M., Richardson, J. A., et al. (2012) microRNA-206 promotes skeletal muscle regeneration and delays progression of Duchenne muscular dystrophy in mice. J. Clin. Invest. 122 2054-2065. doi: 10.1172/JCI62656

Lund, E., Güttinger, S., Calado, A., Dahlberg, J. E., and Kutay, U. (2004). Nuclear export of MicroRNA precursors. Science 303 95-98. doi: 10.1126/science.109 0599

McAlexander, M. A., Phillips, M. J., and Witwer, K. W. (2013). Comparison of methods for miRNA extraction from plasma and quantitative recovery of RNA from plasma and cerebrospinal fluid. Front. Genet. 4:83. doi: 10.3389/fgene. 2013.00083

McCarthy, J. J., and Esser, K. A. (2007) MicroRNA-1 and microRNA-133a expression are decreased during skeletal muscle hypertrophy. J. Appl. Physiol. 102, 306-313. doi: 10.1152/japplphysiol.00932.2006

McCarthy, J. J., Esser, K. A., and Andrade, F. H. (2007). MicroRNA-206 is overexpressed in the diaphragm but not the hindlimb muscle of $\mathrm{mdx}$ mouse. Am. J. Physiol. Cell Physiol. 62, C451-C457. doi: 10.1152/ajpcell. 00077.2007

McCarthy, J. J., Esser, K. A., Peterson, C. A., and Dupont-Versteegden, E. E. (2009). Evidence of MyomiR network regulation of $\beta$-myosin heavy chain gene expression during skeletal muscle atrophy. Physiol. Genomics 39, 219-226. doi: 10.1152/ physiolgenomics.00042.2009

McGee, S. L., Fairlie, E., Garnham, A. P., and Hargreaves, M. (2009). Exercise-induced histone modifications in human skeletal muscle. J. Physiol. 587, 5951-5958. doi: 10.1113/jphysiol.2009.181065

McGee, S. L., Sparling, D., Olson, A. L., and Hargreaves, M. (2006). Exercise increases MEF2- and GEF DNAbinding activity in human skeletal muscle. FASEB J. 20, 348-349.

Menzies, F. M., Ince, P. G., and Shaw, P. J. (2002). Mitochondrial involvement in amyotrophic lateral sclerosis. Neurochem. Int. 40 543-551. doi: 10.1016/S0197-0186 (01)00125-5

Miano, J. M., Long, X., and Fujiwara, K. (2007). Serum response factor: master regulator of the actin cytoskeleton and contractile apparatus. Am. J. Physiol. Cell Physiol. 292, C70-C81. doi: 10.1152/ajpcell.00386.2006

Mitchell, P. S., Parkin, R. K., Kroh, E. M., Fritz, B. R., Wyman, S. K., Pogosova-Agadjanyan, E. L., et al. (2008). Circulating microRNAs as stable blood-based markers for cancer detection. Proc. Natl. Acad. Sci. U.S.A. 105, 10513-10518. doi: 10.1073/pnas.0804549105

Nakajima, K., Takeoka, M., Mori, M. Hashimoto, S., Sakurai, A., Nose H., et al. (2010). Exercise effects on methylation of ASC gene. Int. J. Sports Med. 31, 671-675. doi: 10.1055/s-0029-1246140

Nakasa, T., Ishikawa, M., Shi, M., Shibuya, H., Adachi, N., and Ochi, M. (2010). Acceleration of muscle regeneration by local injection of muscle-specific microRNAs in rat skeletal muscle injury model. J. Cell. Mol. Med. 14, 2495-2505. doi: 10.1111/j.1582-4934.2009.00898.x

Nielsen, S., Scheele, C., Yfanti, C., Akerstrom, T., Nielsen, A. R., Pedersen, B. K., et al. (2010) 
Muscle specific microRNAs are regulated by endurance exercise in human skeletal muscle. J. Physiol. 588, 4029-4037. doi: 10.1113/jphysiol.2010.189860

Nishino, J., Kim, I., Chada, K., and Morrison, S. J. (2008). Hmga2 promotes neural stem cell selfrenewal in young but not old mice by reducing p16Ink4a and p19Arf expression. Cell 135, 227-239. doi: 10.1016/j.cell.2008.09.017

Olsen, P. H., and Ambros, V. (1999). The lin-4 regulatory RNA controls developmental timing in caenorhabditis elegans by blocking LIN-14 protein synthesis after the initiation of translation. Dev. Biol. 216, 671-680. doi: 10.1006/dbio. 1999.9523

Pasinelli, P., and Brown, R. H. (2006). Molecular biology of amyotrophic lateral sclerosis: insights from genetics. Nat. Rev. Neurosci. 7, 710-723. doi: 10.1038/ nrn1971

Perbellini, R., Greco, S., Sarra-Ferraris, G., Cardani, R., Capogrossi, M. C., Meola, G., et al. (2011). Dysregulation and cellular mislocalization of specific miRNAs in myotonic dystrophy type 1 . Neuromuscul. Disord. 21, 81-88. doi: 10.1016/j.nmd.2010.11.012

Phillips, S. M. (2009). Physiologic and molecular bases of muscle hypertrophy and atrophy: impact of resistance exercise on human skeletal muscle (protein and exercise dose effects). Appl. Physiol. Nutr. Metab. 34, 403-410. doi: 10.1139/H09-042

Pigati, L., Yaddanapudi, S. C. S., Iyengar, R., Dong-Ja, K., Hearn, S. A., Danforth, D., et al. (2010). Selective release of MicroRNA species from normal and malignant mammary epithelial cells. PLoS ONE 5:e13515. doi: 10.1371/ journal.pone. 0013515

Pillai, R. S., Bhattacharyya, S. N., Artus, C. G., Zoller, T., Cougot, N., Basyuk, E., et al. (2005). Inhibition of translational initiation by Let-7 MicroRNA in human cells. Science 309, 1573-1576. doi: 10.1126/science. 1115079

Polesskaya, A., Seale, P., and Rudnicki, M. A. (2003). Wnt signaling induces the myogenic specification of resident $\mathrm{CD} 45+$ adult stem cells during muscle regeneration. Cell 113, 841-852. doi: 10.1016/S0092-8674(03)00437-9

Pritchard, C. C., Kroh, E., Wood, B., Arroyo, J. D., Dougherty, K. J., Miyaji, M. M., et al. (2012). Blood cell origin of circulating micrornas: a cautionary note for cancer biomarker studies. Cancer Prev.
Res. 5, 492-497. doi: 10.1158/19406207.CAPR-11-0370

Rao, P. K., Kumar, R. M., Farkhondeh, M., Baskerville, S., and Lodish, H. F. (2006). Myogenic factors that regulate expression of musclespecific microRNAs. Proc. Natl. Acad. Sci. U.S.A. 103, 8721-8726. doi: 10.1073/pnas.0602831103

Reinhart, B. J., Slack, F. J., Basson, M., Pasquinelli, A. E., Bettinger, J. C., Rougvie, A. E., et al. (2000). The 21-nucleotide let-7 RNA regulates developmental timing in Caenorhabditis Elegans. Nature 403, 901-906. doi: 10.1038/35002607

Roberts, T. C., Godfrey, C., McClorey, G., Vader, P., Briggs, D., Gardiner, C., et al. (2013). Extracellular microRNAs are dynamic nonvesicular biomarkers of muscle turnover. Nucleic Acids Res. doi: 10.1093/nar/gkt724. [Epub ahead of print].

Rosenberg, M. I., Georges, S. A., Asawachaicharn, A., Analau, E., and Tapscott, S. J. (2006). MyoD inhibits Fstll and Utrn expression by inducing transcription of miR206. J. Cell Biol. 175, 77-85. doi: 10.1083/jcb.200603039

Rudnicki, M. A., and Jaenisch, R. (1995). The MyoD family of transcription factors and skeletal myogenesis. Bioessays 17, 203-209. doi: 10.1002/bies. 950170306

Russell, A. P. (2010). Molecular regulation of skeletal muscle mass. Clin. Exp. Pharmacol. Physiol. 37, 378-384. doi: 10.1111/j.1440-1681. 2009.05265.x

Russell, A. P., Feilchenfeldt, J., Schreiber, S., Praz, M., Crettenand, A., Gobelet, C., et al. (2003). Endurance training in humans leads to fiber type-specific increases in levels of peroxisome proliferator-activated receptor-gamma coactivator-1 and peroxisome proliferatoractivated receptor-alpha in skeletal muscle. Diabetes 52, 2874-2881. doi: 10.2337/diabetes.52.12.2874

Russell, A. P., Hesselink, M. K., Lo, S. K., and Schrauwen, P. (2005) Regulation of metabolic transcriptional co-activators and transcription factors with acute exercise. FASEB J. 19, 986-988. doi: 10.1096/fj.04-3168fje

Russell, A. P., Lamon, S., Boon, H., Wada, S., Guller, I., Brown, E. L., et al. (2013). Regulation of miRNAs in human skeletal muscle following acute endurance exercise and short term endurance training. J. Physiol. 591, 4637-4653. doi: 10.1113/jphysiol. 2013.255695
Russell, A. P., Wada, S., Vergani, L., Hock, M. B., Lamon, S., Leger, B., et al. (2012). Disruption of skeletal muscle mitochondrial network genes and miRNAs in amyotrophic lateral sclerosis. Neurobiol. Dis. 49C, 107-117.

Sabourin, L. A., and Rudnicki, M. A. (2000). The molecular regulation of myogenesis. Clin. Genet. 57, 16-25. doi: 10.1034/j.1399-0004. 2000.570103.x

Sawada, S., Kon, M., Wada, S., Ushida, T., Suzuki, K., and Akimoto, T. (2013). Profiling of Circulating MicroRNAs after a bout of acute resistance exercise in humans. PLoS ONE 8:e70823. doi: 10.1371/ journal.pone.0070823

Schabort, E. J., Van Der Merwe, M., Loos, B., Moore, F. P., and Niesler, C. U. (2009). TGF-beta's delay skeletal muscle progenitor cell differentiation in an isoform-independent manner. Exp. Cell Res. 315, 373-384. doi: 10.1016/j.yexcr 2008.10.037

Short, K. R., Vittone, J. L., Bigelow, M. L., Proctor, D. N., Rizza, R A., Coenen-Schimke, J. M., et al. (2003). Impact of aerobic exercise training on age-related changes in insulin sensitivity and muscle oxidative capacity. Diabetes 52 , 1888-1896. doi: 10.2337/diabetes. 52.8 .1888

Small, E. M., O’Rourke, J. R., Moresi V., Sutherland, L. B., McAnally, J., Gerard, R. D., et al. (2010). Regulation of PI3-kinase/Akt signaling by muscle-enriched microRNA-486. Proc. Natl. Acad. Sci. U.S.A. 107, 4218-4223. doi: 10.1073/pnas. 1000300107

Sood, P., Krek, A., Zavolan, M., Macino, G., and Rajewsky, N. (2006). Celltype-specific signatures of microRNAs on target mRNA expression. Proc. Natl. Acad. Sci. U.S.A. 103, 2746-2751. doi: 10.1073/pnas.051 1045103

Sweetman, D., Goljanek, K., Rathjen, T., Oustanina, S., Braun, T., Dalmay, T., et al. (2008). Specific requirements of MRFs for the expression of muscle specific microRNAs, miR1, miR-206 and miR-133. Dev. Biol. 321, 491-499. doi: 10.1016/j.ydbio. 2008.06.019

Sylvius, N., Bonne, G., Straatman, K., Reddy, T., Gant, T. W., and Shackleton, S. (2011). MicroRNA expression profiling in patients with lamin $\mathrm{A} / \mathrm{C}$-associated muscular dystrophy. FASEB J. 25, 3966-3978. doi: 10.1096/fi.11-182915

Symons, T. B., Sheffield-Moore, M., Wolfe, R. R., and PaddonJones, D. (2009). A moderate serving of high-quality protein maximally stimulates skeletal muscle protein synthesis in young and elderly subjects. J. Am. Diet. Assoc. 109, 1582-1586. doi: 10.1016/j.jada.2009.06.369

Tajbakhsh, S., Bober, E., Babinet, C., Pournin, S., Arnold, H., and Buckingham, M. (1996). Gene targeting the myf-5 locus with nlacZ reveals expression of this myogenic factor in mature skeletal muscle fibres as well as early embryonic muscle. Dev. Dyn. 206, 291-300 doi: 10.1002/(SICI) 1097-0177(1996 07)206:3<291::AID-AJA6>3.0.CO; 2-D

Tanimura, Y., Kon, M., Shimizu, K., Kimura, F., Kono, I., and Ajisaka, R. (2009). Effect of 6-day intense Kendo training on lymphocyte counts and its expression of CD95. Eur. J. Appl. Physiol. 107, 227-233. doi: 10.1007/s00421-009-1119-1

Terzis, G., Georgiadis, G., Stratakos, G., Vogiatzis, I., Kavouras, S., Manta, P., et al. (2008). Resistance exercise-induced increase in muscle mass correlates with p70S6 kinase phosphorylation in human subjects. Eur. J. Appl. Physiol. 102, 145-152. doi: 10.1007/s00421-0070564-y

Timmons, J. A., Knudsen, S., Rankinen, T., Koch, L. G., Sarzynski, M., Jensen, T., et al. (2010). Using molecular classification to predict gains in maximal aerobic capacity following endurance exercise training in humans. J. Appl. Physiol. 108, 1487-1496. doi: 10.1152/japplphysiol.01295.2009

Tintignac, L. A., Lagirand, J., Batonnet, S., Sirri, V., Leibovitch, M. P., and Leibovitch, S. A. (2005). Degradation of MyoD mediated by the SCF (MAFbx) ubiquitin ligase. J. Biol. Chem. 280, 2847-2856. doi: 10.1074/jbc.M411346200

Tonevitsky, A., Maltseva, D., Abbasi, A., Samatov, T., Sakharov, D., Shkurnikov, M., et al. (2013). Dynamically regulated miRNAmRNA networks revealed by exercise. BMC Physiol. 13:9. doi: 10.1186/1472-6793-13-9

Turchinovich, A., Weiz, L., Langheinz, A., and Burwinkel, B. (2011). Characterization of extracellular circulating microRNA. Nucleic Acids Res. 39, 7223-7233. doi: 10.1093/nar/gkr254

Uhlemann, M., Möbius-Winkler, S., Fikenzer, S., Adam, J., Redlich, M., Möhlenkamp, S., et al. (2012). Circulating microRNA126 increases after different forms of endurance exercise in healthy adults. Eur. J. Prev. Cardiol. 
doi: $\quad 10.1177 / 2047487312467902$. [Epub ahead of print].

Valadi, H., Ekstrom, K., Bossios, A., Sjostrand, M., Lee, J. J., and Lotvall, J. O. (2007). Exosome-mediated transfer of mRNAs and microRNAs is a novel mechanism of genetic exchange between cells. Nat. Cell Biol. 9, 654-659. doi: 10.1038/ncb1596

Vickers, K. C., Palmisano, B. T., Shoucri, B. M., Shamburek, R. D., and Remaley, A. T. (2011). MicroRNAs are transported in plasma and delivered to recipient cells by high-density lipoproteins. Nat. Cell Biol. 13, 423-433. doi: 10.1038/ncb2210

Wadley, G. D., Konstantopoulos, N., Macaulay, L., Howlett, K. F., Garnham, A., Hargreaves, M., et al. (2007). Increased insulinstimulated Akt pSer473 and cytosolic SHP2 protein abundance in human skeletal muscle following acute exercise and short-term training. J. Appl. Physiol. 102, 1624-1631. doi: 10.1152/jappl physiol.00821.2006

Wightman, B., Ha, I., and Ruvkun, G. (2004). Posttranscriptional regulation of the heterochronic gene lin14 by lin- 4 mediates temporal pattern formation in C. elegans. Cell 116, 855-862. doi: 10.1016/00928674(93)90530-4

Yamakuchi, M., and Lowenstein, C. J. (2009). MiR-34, SIRT1, and p53: the feedback loop. Cell Cycle 8, 712-715. doi: $10.4161 /$ cc.8.5.7753

Yarasheski, K. E., Zachwieja, J. J., and Bier, D. M. (1993). Acute effects of resistance exercise on muscle protein synthesis rate in young and elderly men and women. Am. J. Physiol. Endocrinol. Metab. 265, E210-E214.

Yuasa, K., Hagiwara, Y., Ando, M., Nakamura, A., Takeda, S., and Hijikata, T. (2008). MicroRNA206 is highly expressed in newly formed muscle fibers: implications regarding potential for muscle regeneration and maturation in muscular dystrophy. Cell Struct. Funct. 33, 163-169. doi: 10.1247/ csf.08022

Zhang, Y., Liu, D., Chen, X., Li, J., Li, L., Bian, Z., et al. (2010). Secreted monocytic miR-150 enhances targeted endothelial cell migration. Mol. Cell 39, 133-144. doi: 10.1016/ j.molcel.2010.06.010

Zhao, C., Sun, G., Li, S., Lang, M.-F., Yang, S., Li, W., et al. (2010). MicroRNA let-7b regulates neural stem cell proliferation and differentiation by targeting nuclear receptor TLX signaling. Proc. Natl. Acad. Sci. U.S.A. 107, 1876-1881. doi: 10.1073/pnas.0908750107

Conflict of Interest Statement: The authors declare that the research was conducted in the absence of any commercial or financial relationships that could be construed as a potential conflict of interest.
Received: 04 August 2013; accepted: 09 September 2013; published online: 30 September 2013.

Citation: Zacharewicz E, Lamon S and Russell AP (2013) MicroRNAs in skeletal muscle and their regulation with exercise, ageing, and disease. Front. Physiol. 4:266. doi: 10.3389/fphys. 2013.00266

This article was submitted to Striated Muscle Physiology, a section of the journal Frontiers in Physiology.

Copyright ( 2013 Zacharewicz, Lamon and Russell. This is an open-access article distributed under the terms of the Creative Commons Attribution License (CC BY). The use, distribution or reproduction in other forums is permitted, provided the original author(s) or licensor are credited and that the original publication in this journal is cited, in accordance with accepted academic practice. No use, distribution or reproduction is permitted which does not comply with these terms. 